\title{
EXPLORING CLASS, NATION, AND XENOCENTRISM IN INDONESIAN CASSETTE RETAIL OUTLETS ${ }^{1}$
}

\section{Jeremy Wallach}

Like their fellow scholars in the humanities and social sciences, many ethnomusicologists over the last decade have grown preoccupied with the question of how expressive forms are used to construct national cultures. Their findings have been consistent for the most part with those of researchers in other fields: namely that social agents manufacture "national" musics by strategically domesticating signs of the global modern and selectively appropriating signs of the subnational local. These two simultaneous processes result in a more or less persuasive but always unstable synthesis, the meanings of which are always subject to contestation. ${ }^{2}$ Indonesian popular music, of course, provides us with many examples of nationalized hybrid

\footnotetext{
${ }^{1}$ I am grateful to the Indonesian performers, producers, proprietors, music industry personnel, and fans who helped me with this project. I wish to thank in particular Ahmad Najib, Lala Hamid, Jan N. Djuhana, Edy Singh, Robin Malau, and Harry Roesli for their valuable input and assistance. I received helpful comments on earlier drafts of this essay from Matt Tomlinson, Webb Keane, Carol Muller, Greg Urban, Sandra Barnes, Sharon Wallach, and Benedict Anderson. Their suggestions have greatly improved the final result; the shortcomings that remain are entirely my own.

2 Thomas Turino, "Signs of Imagination, Identity, and Experience: A Peircean Semiotic Theory for Music," Ethnomusicology 43,2 (1999): 221-255. See also in the same issue, Kenneth Bilby, "Roots Explosion': Indigenization and Cosmopolitanism in Contemporary Surinamese Popular Music," Ethnomusicology 43,2 (1999): 256-296 and T. M. Scruggs, "Let's Enjoy as Nicaraguans: The Use of Music in the Construction of a Nicaraguan National Consciousness," Ethnomusicology 43,2 (1999): 297-321. For a somewhat different perspective on the relationship between global and local sounds in a self-consciously national genre, see Paul Greene, "Mixed Messages: Unsettled Cosmopolitanisms in Nepali Pop," Popular Music 20,2 (2001): 169-188.
} 
80 Jeremy Wallach

formations forged through a creative process of dual appropriation, in which elements as diverse as Indian film music, Anglo-American hard rock, reggae, and disco are combined with the sounds of gamelan and other indigenous regional music traditions to create musical genres that aspire to be both "modern" and "Indonesian."

Given their newfound interest in the musical construction of the nation, it is surprising that so few ethnomusicologists in Indonesia and elsewhere have thought to study record stores, where national musical genres are displayed, contrasted, and categorized. As I hope to demonstrate in this essay, recorded music retail outlets provide a unique vantage point from which to view the contradictions of class, nation, and modernity in the Indonesian metropole and beyond.

Ethnomusicologists who visit Indonesia do tend to spend a significant amount of time in local cassette stores, but they rarely write about them in much detail. Those that do describe a bewildering spectacle of diverse musics both strange and familiar. ${ }^{3}$ In this essay, I take a systematic approach to the cultural space of the cassette store in its various incarnations and examine the social and economic forces that shape it. Against the backdrop of current trends in the Indonesian music industry, I investigate shelf categories, store layouts, decorations, employee and customer behavior, and the ratios of imported to domestic product that characterize the various sites where music is purchased in Jakarta and other Indonesian cities. Several patterns emerge from this exploration. In particular, a survey of the different types of music retail outlets reveals signs of the social and economic bifurcation that has long characterized Indonesian society and which was exacerbated both by the New Order regime's policies and the aftermath of the 1997-98 economic crisis. The hierarchical presentation of musical genres found in nearly every Indonesian cassette retail outlet provides an important example of how musical genre is linked to class-inflected notions of prestige and value that divide the Indonesian national public.

For the following analysis, I draw upon Pierre Bourdieu's theories of social stratification and cultural consumption practices. ${ }^{4}$ In his analysis of French society, Bourdieu argues against a direct correlation between socioeconomic status and cultural preferences, instead asserting that certain embodied forms of knowledge become sources of "cultural capital," a separate entity from economic capital. Thus, in Bourdieu's view, cultural status and prestige do not follow directly from the relations of production, but are negotiated in a cultural field of aesthetic alternatives in which some choices are more highly valued than others.

\section{Genre and Gengsi: Indonesian Versus Foreign Popular Music}

Asking an Indonesian teenager why he or she likes a particular song, artist, or genre tends to elicit the response, "Ya, suka aja" (I just like it, that's all). But when one digs

\footnotetext{
${ }^{3}$ For example, Marc Perlman, "The Traditional Javanese Performing Arts in the Twilight of the New Order: Two Letters from Solo," Indonesia 68 (October 1999): 1-37.

4 Pierre Bourdieu, Distinction: A Social Critique of the Judgment of Taste, trans. Richard Nice (Cambridge: Harvard University Press, 1984).
} 
deeper, one discovers a complex moral economy in which musical genres are ranked vis-à-vis one another based on a largely implicit system of social distinction, which in Jakartanese is summed up by the Hokkien Chinese-derived term gengsi (status consciousness, prestige). These relative rankings of social prestige and power in many cases determine which genres and artists Indonesians readily admit to liking, and which they do not.

In Indonesia, different popular music genres signify differing quantities of cultural capital, and the genres that signify the highest social status do not originate from Indonesia at all, but rather from the West, primarily Britain and the United States. ${ }^{5}$ Second in order of status is Indonesian music that strongly resembles Western popular music musically, if not always lyrically; this is usually classified as pop Indonesia. This variegated genre encompasses several subgenres; these include sophisticated, jazz and R\&B-influenced pop kelas atas (upper-class pop) and youth-oriented pop alternatif, which draws inspiration from recent Western rock styles.

The other major category of Indonesian popular music is dangdut, that irrepressible, electrified hybrid of Middle Eastern, South Asian, Western, and indigenous musical elements that enjoys an enormous nationwide audience of ordinary Indonesians. Despite nearly two decades of recurrent, hyperbolic mass-media accounts of dangdut's "new" and growing acceptability to the Indonesian middle class, many middle-class and elite Indonesians still openly revile the genre, which has not lost its associations with lewd behavior, low-class "village" attitudes, and general aesthetic tackiness, and remains tied to performance and listening contexts defined by their proletarian, unruly character. ${ }^{6}$ The most prevalent and injurious epithet used to derogate dangdut music is kampungan, a culturally loaded term which can be loosely translated as "vulgar, low-class, and repellently characteristic of backward village life," or in James Siegel's words, "hickish."7 Thus dangdut is always subordinate to the more Westernized and middle-class-oriented pop Indonesia and can never be a source of gengsi. Similarly, musik daerah (regional music), which appeals to a subnational,

${ }^{5}$ Kuan-Hsing Chen questions the continued popularity of American cultural products in East Asia despite the presence of fully developed, robust national culture industries in most East Asian countries. He concludes that, "The key to the sway of this American imperialism has lain in its ability to insert itself in the geo-colonial space as the imaginary figure of modernity." While Western popular culture is indeed inextricably linked with modernity and development in Indonesia, it is certainly possible that Indonesians' enthusiasm for Western music may stem more from their enjoyment of its sensual qualities than from ideological brainwashing. Kuan-Hsing Chen, "America in East Asia: The Club 51 Syndrome," New Left Review 12 (2001): 73-87, p. 85.

${ }^{6}$ For discussions of the emergence and popularization of dangdut, see William Frederick, "Rhoma Irama and the Dangdut Style: Aspects of Contemporary Indonesian Popular Culture," Indonesia 32 (1982): 103130; and James Siegel, Solo in the New Order: Language and Hierarchy in an Indonesia City (Princeton: Princeton University Press, 1986), pp. 215-18. For more contemporary accounts of dangdut performance at the grassroots level and the music's incomplete assimilation into the middle-class-defined mainstream see Susan Browne, The Gender Implications of Dangdut Kampungan: Indonesian 'Low-Class' Popular Music (Melbourne: Monash University Institute for Asian Studies Working Paper No. 109, 2000), and Jeremy Wallach, "Modern Noise and Ethnic Accents: Indonesian Popular Music in the Era of Reformasi" (PhD dissertation, University of Pennsylvania, 2002).

${ }^{7}$ Siegel, Solo in the New Order, p. 215. 
regional, or "ethnic" audience, cannot be a source of gengsi at the national level. Like dangdut, these musics (which range from highly idiosyncratic local traditions captured on tape to straightforward studio-produced Western-style pop sung in regional languages) tend to be popular among working-class and rural consumers but disavowed by middle-class city dwellers.

A final Indonesian genre to be considered here is "underground" or "indie" rock music. ${ }^{8}$ Associated primarily with male high school and university student audiences, bands in the Indonesian underground play loud, rebellious rock music that often contains explicitly political messages. While their music closely resembles that of Western groups and is often sung in English, the preferred method of producing, performing, and distributing Indonesian underground music is defiantly localist and grassroots-based, operating outside the channels of the commercial music industry. Therefore, underground music exists in an ambiguous relationship to the status hierarchy of popular music in Indonesia. Rather than signifying social status in society at large, underground rock indexes a body of specialized knowledge of value to a selfselecting minority of listeners; it can therefore be said to possess "subcultural capital." 9 But in its own way, the underground music movement is premised on the same assiumption that animates the mainstream pop industry: namely, that Western music is superior to indigenous styles.

\section{Music and "Xenocentrism"}

When I was teaching a cultural anthropology course at Universitas Atma Jaya, a private university in Central Jakarta, an Indonesian colleague advised me to introduce my students to the term xenosentrik (xenocentric) in addition to etnosentrik (ethnocentric) on the first day of class. I knew that it was customary for anthropology instructors in the United States to introduce beginning students to the concept (and hazards) of ethnocentrism-the belief that one's own culture is superior to all othersin order to contrast it to the relativistic approach of mainstream cultural anthropology toward cultural differences. Teaching students about the concept of xenocentrism-the belief, not uncommon in postcolonial societies, that a foreign culture (the West, for example) is superior to all others, including one's own-was, however, a new experience for me. Yet it soon became clear to me why such a term was necessary in order to teach the idea of cultural relativism to Indonesian undergraduates: "xenocentric" described well the attitude my students, like so many other middle- and upper-class Indonesians, held about a range of cultural phenomena, including business, government, religion (among both Muslims, who look toward the Middle East, and Christians, who look toward the West), cinema, technology, and, not least, popular music. In relation to this last item, my research findings strongly suggest that the

\footnotetext{
${ }^{8}$ For more information about the history and development of the underground music movement in Indonesia, see Jeremy Wallach, "'Goodbye My Blind Majesty': Music, Language, and Politics in the Indonesian Underground," in Global Pop Music and the Politics of Language Choice, ed. Harris M. Berger and Michael T. Carroll. (Jackson: University Press of Mississippi, forthcoming 2003).

${ }^{9}$ For further elucidation of the concept of "subcultural capital," see Sarah Thornton, Club Cultures: Music, Media, and Subcultural Capital (Hanover: University Press of New England, 1996).
} 
strategies by which cassette stores display their wares tend to replicate and reinforce, if not create, a xenocentric status hierarchy which places Western (primarily British and American) music at the top, and ethnic and working-class-oriented Indonesian genres at the low end of the gengsi scale.

As Bourdieu would have predicted, belief in the artistic superiority of Western music is not purely a function of socioeconomic class position, though there is a certainly a correlation between such attitudes and middle- or upper-class standing. I spoke with many working-class music fans whose opinions of Indonesian popular music, especially dangdut, were as uncomplimentary as those held by members of the middle class, if not more so. For example, walking home from campus one day I was accosted by a middle-aged man hanging out on the corner of Jalan Sudirman and Jalan Teluk Betung in Central Jakarta. He seemed more than a little inebriated and was talking and joking with two women whom I had seen at local dangdut bars and whom an informant had told me worked as prostitutes. Speaking in broken but understandable English peppered with American slang expressions, he asked me what I was in doing in Indonesia. When I mentioned that I was interested in studying national popular music genres like dangdut and jaipongan (a nationalized dance music from West Java), he became surprised and indignant. The following is a partial reconstruction of his remarks from my 1997 field notes:

Oh, God! I can't believe you're studying that. Dangdut and jaipong-I don't know why the Indonesian people like this music. It is ah . . . [hesitation, as though searching for the right expression in English] ... from the village. It is ... ["Kampungan?" I asked him] . . . Yes! That's it. As for me, I like Grand Funk Railroad; Chicago; Deep Purple; Uriah Heep; [a name I could not identify]; Emerson, Lake, and Palmer; Jimi Hendrix; blues ... ["Flower Generation?" I ask] ... Yes, man! I'm forty-I was in that generation! When I was still in high school, twenty years ago, my friends and I were proud to have the posters: Janis Joplin; Emerson, Lake, and Palmer; the Beatles. But people in Indonesia-there is a problem with apresiasi-appreciation of good music. [ . . . ] Speaking for me-I don't think I'm kebarat-baratan [Westernized], more Western than Western guys, but I appreciate Western music: blues, klasik [classical music], rock. That is what I think. It's interesting talking to you ...

This man's comments not only reveal the easy contempt some urban dwellers hold for Indonesian national popular music genres, but also illustrate the important connection between Western popular music-especially rock-and masculine generational identity, which is clearly a factor in the rise of the musical underground in the 1990s. Knowledge of a particular Western musical canon, in this case rock music from the 1960s and 1970s, associated in Indonesia with the "Flower Generation," was a source of cultural capital for the speaker. In contrast, he seemed almost embarrassed by the popularity of dangdut and jaipongan, which for him served as a reminder of the backwardness of his fellow citizens and their inability to appreciate "good music."

Some more thoughtful music fans expressed ambivalence about the musical prestige hierarchy in Indonesia while not denying the power it wields. The following is an excerpt from an e-mail I received from a highly educated Jakartan small businessman 
and former student activist in response to a query concerning his favorite kind of music.

Hallo Jeremy,

Langsung aja nich...

Kalau ditanya soal musik, aku paling bingung ngejawabnya. Aku memang suka musik. But what kind of music do I like? This is really confused me. Aku mau jujur aja. Sebenarnya aku ini snobist! Snobist yang sok tahu, biar nggak dibilang ketinggalan jaman, gitu. Tapi akhirnya, ya suka juga. Awalnya memang snob. Kata Harry Roesly, apresiator musik di Indonesia umumnya berawal dari snob. Banyak juga musisi negri ini yang snobist duluan. Biar nggak dikatakan kampungan, lalu coba-coba musik barat, trus kebablasan jadi pemain. Itu biasa. Namanya juga anak muda. Coba tanya Pra, atau yang lainnya tentang latar belakang mereka bermain musik barat seperti fusion, rock, atau sekarang yang lagi trend di sini, ska. Selain itu, memainkan musik Barat tentu lebih praktis. Bayangkan, kalau main musik trad. yang instrumentnya seberat gajah sekarat, macam gong, saron [ ... ] dll.

Lho, kok jadi ngelantur. Soal apa tadi? Oh...ya, soal musik yang aku suka. Jelas dong, yang kusuka kan jazz kuno, macam Louis Armstrong, Mile Davis, Herbie Hancock, Oscar Peterson dll. Yang jelas saya tidak membatasi diri hanya dengar aliran musik tertentu. Hanya lebih enjoy dengan yang saya sebut tadi. Itu saja. Masa' kalau lagi disco pake lagu gituan. Pokoknya lihat-lihat kesempatannya lah! [...]

Hello Jeremy,

I'll get directly to the point.

If asked about music, I get very confused how to answer. I certainly like music. But what kind of music do I like? This really confused me. I'll just be honest. Actually, I'm a snob [snobist]! A snob who's a know-it-all, just so it isn't said that he is behind the times, like that. But ultimately yeah, I like it that way. In the beginning, certainly a snob. Harry Roesli [a well-known composer and recording artist] says appreciators of music in Indonesia generally begin as snobs. There are also many musicians from this country who were snobs at first. So as not to be considered backward or low class [kampungan], they mess around amateurishly with Western music, then instantly think they've become players. That's what normally happens. You know, kids are like that. Try asking Pra [Budidharma, the bassist of ethnic jazz fusion group Krakatau] or others about their background playing Western music like fusion, rock, or the music currently in vogue here, ska. Aside from that, playing Western music is certainly more practical. Imagine, if you want to play traditional music, the instruments are as heavy as an elephant in its death throes, like gong, saron [... ] etc.

$\mathrm{Hmmm}$... I'm drifting here. What was I talking about just now? Oh ... yeah, the matter of music I like. It's clear of course, what I like is old jazz, like Louis Armstrong, Mile Davis, Herbie Hancock, Oscar Peterson, etc. What's clear is that I don't limit myself by only listening to a particular stream of music. I only enjoy more the music I just mentioned. That's all. It would be impossible if I'm disco 
dancing to use songs like that [old jazz]! The main thing is to look at the situation lah!

After expressing discomfort with the apparent elitism of his musical taste, the writer admits he likes one of the most prestigious categories of music, Western jazz. Moreover, he prefers jazz kuno (old jazz), not the watered down jazz/rock/pop fusion that dominates the Indonesian (and international) jazz market. By writing that musicians turn to Western music in order not to be considered kampungan, the writer implies that non-Western-sounding music in Indonesia, including traditional music with its impractical, heavy instruments, is backward and low class. Yet to subscribe to this view is to be a snobist, that is, to care too much about gengsi. So finally the writer disavows his elitism with the quite plausible claim that he listens to all kinds of music depending on the situation and that he just happens to enjoy traditional jazz best.

As an intellectual familiar with post-structuralism and postcolonial theory, the writer is uncomfortable with the argument that Western music truly is superior to indigenous Indonesian music. He even cites (somewhat unconvincingly) logistical problems with moving heavy instruments as a reason why musicians choose to play Western instead of traditional music, as though practicality was of greater concern to them than artistic value. Nevertheless, Indonesians from a variety of social and class backgrounds share the view he describes but does not quite endorse, according to which standards of musical excellence emanate from a Western elsewhere. This elsewhere is spatially and sometimes temporally distant, as in the case of 1950s jazz or 1970s hard rock. It is not difficult to associate this attitude with the brainwashing effects of globalized Western popular culture. I would argue, however, that in Indonesia such a view is also part of a local strategy for distinguishing oneself from "low class" and rural Indonesians through the self-conscious demonstration of cultural capital. Evidence for this interpretation can be found in the conspicuous class-based differences in musical consumption in Indonesia. The next section of the essay continues our investigation of the context of musical commerce in Indonesia, and investigates how middle-class gengsi concerns and a xenocentric view of artistic quality have an impact upon the culture and economics of popular music in Indonesia.

\section{Genre, Class, and Status: A View of the Indonesian Music Industry}

The music retail outlets discussed in this essay operate in the social and economic context of the Indonesian music industry, which is in the midst of an historic transition from a highly segmented to a more unified music market. ${ }^{10}$ Because Indonesia is a country in which class differences are obvious, frankly acknowledged, and pervasive in social life, music industry workers tend to view the Indonesian popular music market not as an entity composed of an undifferentiated mass of consumers, but as a ladder of different socioeconomic classes. According to the marketing director of the Indonesian Repertoire and Promotions Division of a major transnational record company with extensive operations in Indonesia, these levels were commonly labeled

\footnotetext{
${ }^{10}$ For a useful survey of recent developments in the Indonesian music industry (both mainstream and underground), see Krishna Sen and David Hill, Media, Culture, and Politics in Indonesia (Melbourne: Oxford University Press, 2000), pp. 164-193.
} 
A to $F$. She stated that A and B class consumers in large cities (Jakarta, Bandung, Surabaya, Medan) prefer Western music, while their counterparts in smaller cities prefer upmarket pop Indonesia. C and D consumers' tastes tended toward sentimental, melodramatic pop (pop melankolis, also known pejoratively as pop cengeng, "weepy pop"11) and, of course, dangdut. She added dryly that the " $\mathrm{D}$ " virtually stood for dangdut when one was discussing the musical preferences of that market segment. Finally, the crowded $E$ and $F$ socioeconomic levels were composed of people too poor to buy music and did not factor into the industry's marketing strategies.

While most Indonesian music consumers do not employ these music industry labels, they tend explicitly to associate particular musical genres with either menengah ke atas ("middle to upper") or "menengah ke bawah" (middle to below) consumers. Only children's pop (pop anak-anak), which appeals to children at all levels, and underground music, which attracts a cross-class youth subcultural audience, constitute partial exceptions to this rule. For example, "AB"-oriented pop kelas atas (upper-class pop), exemplified by the work of singers Ruth Sahanaya, Titi DJ, Krisdayanti, and Rossa, is readily distinguishable from more working class-oriented pop music by its slicker, R\&B-influenced production, jazzy arrangements, and upbeat lyrics, as well as significant differences in promotional strategies and artists' images.

The class-inflected status hierarchy of musical genres is reflected in the range of retail prices for different types of cassette. Legitimate (that is, nonpirated) cassette prices in Indonesia are generally pas (fixed; exact; not subject to bargaining) and thus are remarkably consistent regardless of the location of purchase, though at smaller stalls one is more likely to receive a slight discount for buying several cassettes at once. The following is a list of cassette prices by genre in Jakarta in late June 2000.12

Western: Rp. 20,000 (at the time, approximately $\$ 2.50$ US)

Pop Indonesia: Rp. 16,000 to Rp. 18,000 (\$2.00 to $\$ 2.25$ )

Dangdut: Rp. 12,000 to Rp. 14,000 ( $\$ 1.50$ to $\$ 1.75$ )

Regional Music (Musik Daerah): Rp. 10,000 to Rp. 13,000 (\$1.25 to $\$ 1.63$ )

Underground [independently produced and distributed]: Rp. 10,000 to Rp. 17,000 (\$1.25 to $\$ 2.13$ )

Although the prices of Western cassettes are too high for many Indonesians to afford (twice as much as the cost of some musik daerah cassettes), they are nevertheless much lower than the retail prices of Western music in the West. The price differential is accomplished by manufacturing the cassettes domestically under license from multinational media corporations. Compact disks are also locally manufactured, but they are far more expensive than cassettes, which remain by far the best-selling format in Indonesia. In June 2000, locally produced Western compact disks could cost as much as Rp. 80,000 (at the time, approximately $\$ 10.00$ US), while compact disks by Indonesian artists cost approximately Rp. 50,000 (\$6.25). With prices like these,

${ }^{11}$ For a discussion of the cengeng qualities of certain pop Indonesia songs, see Philip Yampolsky, "Hati Yang Luka,' An Indonesian Hit," Indonesia 47 (April 1989): 1-17.

12 Retail prices for recorded music increased steadily during the period of my dissertation fieldwork (19992000), a consequence of rising production costs and the weakness of Indonesia's currency. 
compact disks are considered a format designated for "AB" consumers. Very few dangdut recordings are ever released on compact disk; a dangdut producer once told me such items would not sell well and would only be used as ideal masters for the production of pirated cassettes. Among new releases, only pop Indonesia albums that have first been commercially successful on cassette are released on compact disk.

\section{Krismon and the Transformation of the Indonesian Music Market}

For much of the 1980s and 1990s, the sheer numbers of consumers in the so-called $\mathrm{C}$ and $\mathrm{D}$ markets compensated for their relatively weak purchasing power, and in fact musical genres such as dangdut that targeted this audience, while low on the gengsi scale, were quite profitable for record companies. In the early and mid-1990s it was not unusual for a dangdut cassette containing a hit song to sell more than a million legitimate copies-an unheard-of amount for pop records at the time. This situation changed drastically in the aftermath of the 1997-98 economic catastrophe.

A comparison of music sales in the years before and after Indonesia's economic collapse provides a telling indication of the relative ability of Indonesians from different social classes to weather the crisis. The following table is sorted by foreign and local music, and by consumer format. Almost all music sold in Indonesia is in the form of prerecorded cassettes, but music is also available on compact disk, video compact disks (VCD), and laser disk (LD). The latter two formats, obscure or unknown in the West, contain images as well as sounds, and are used to accompany karaoke performance. They primarily feature Indonesian music.

Table 1: Recorded Music Sales Data for Indonesia (units sold), 1996-199913

\begin{tabular}{|l|c|c|c|r|}
\hline \multicolumn{1}{|c|}{ Type } & 1996 & 1997 & 1998 & 1999 (Oct.) \\
\hline Indo. cassettes & $65,396,589$ & $49,794,676$ & $27,635,739$ & $30,100,077$ \\
\hline Foreign cass. & $11,374,089$ & $14,005,340$ & $9,637,200$ & $11,395,590$ \\
\hline Indo. CDs & 265,475 & 778,370 & 315,910 & 532,900 \\
\hline Foreign CDs & 474,980 & $2,053,840$ & $2,732,410$ & $2,086,290$ \\
\hline Karaoke VCDs & 19,500 & 701,870 & $1,335,390$ & $4,196,590$ \\
\hline LD Karaoke & 21,375 & 21,975 & 2,205 & 1,050 \\
\hline TOTAL & $77,552,008$ & $67,356,071$ & $41,658,674$ & $48,312,497$ \\
\hline
\end{tabular}

13 Adapted from K. S. Theodore, "Industri Musik Indonesia di Ujung Abad Ke 20," Buletin ASIRI 5 (1999): 10-11. 
88 Jeremy Wallach

During the economic crisis, the upper and middle classes, with their high rates of personal savings, suffered far less than the urban poor, who had little or no savings and could not cope with the steeply rising prices of consumer goods. A striking statistic from the above table is that sales of the highest-priced, most prestigious commodity, foreign compact disks, actually increased 33 percent between 1997 and 1998 , during the height of the economic crisis. It is tempting to posit a perverse kind of gengsi logic behind this increase, and behind the fact that the number of foreign compact disks sold in Indonesia dips slightly the following year. According to such a logic, conspicuous consumption in the form of purchasing Western compact disks during the height of an economic crisis would powerfully demonstrate one's elite status and separation from the immiserated poor, many of whom were now unable to buy even the cheapest local cassettes.

In October 1999, the sale of cassettes by Indonesian artists over the previous eight months amounted to less than half of the total figure for 1996. Due to competition from the rapidly growing VCD medium (which is even more dominated by piracy than cassettes are), it is possible that Indonesian cassette sales will never rebound completely, even if the economic outlook of the country improves. This situation led some recently arrived multinational recording companies to conclude that the "middle to lower" market segment was no longer profitable, a result of those consumers' decreased spending power and habit of buying readily available pirated cassettes.

In post-crisis Indonesia many of the most successful new recordings have been by pop alternatif and ska groups like Sheila on 7 and Jun Fan Gung Foo (both artists for Sony Music Indonesia) that have crossed over to an economically diverse audience. This has often occurred against the expectations of record label personnel, who did not anticipate such high sales (Sheila on 7's eponymous first album has sold over one million copies; the second album by the stylistically similar band Padi has reportedly sold three times that amount). That pop alternatif artists associated with urban middle class youth have apparently become accepted in lower social strata is evidence for a claim I heard several people in the Indonesian music industry make: the current youth market in Indonesia is far more uniform across class boundaries than in previous generations, a situation attributed to the influence of MTV and other recently introduced outlets for global popular culture. If this claim is true, however, the phenomenon does not contradict or counteract widening social inequality in Indonesia in the face of both economic globalization and economic crisis. Indeed, three decades of the New Order's aggressive economic development policies may well have resulted in a more unified popular culture coupled with a more polarized society.

\section{Music Consumption at the Ground Level: A Taxonomy of Jakarta's Music Retail Outlets}

If we confine ourselves to the "legitimate" music market and ignore for the moment pirated merchandise, we find that the prices and products for sale in different kinds of retail outlets do not differ markedly. The manner in which recordings are displayed is also similar from one outlet to the next, but the experiences of shopping for cassettes in a large music store as opposed to a small cassette stall can differ widely. In the former, one usually finds that well over half of the music for sale is imported. By contrast, 
cassette stalls that operate in the informal, "bazaar" economy nearly always sell Western cassettes, but these usually account for less than 25 percent of total shelf space. The precise ratio of imported to Indonesian cassettes varies depending on the economic circumstances of the surrounding neighborhood. Cassette stalls in the poorest Jakarta kampung, for instance, generally offer very few Western cassettes for sale (and no compact disks of any sort), but feature a wide selection of dangdut cassettes. ${ }^{14}$

\section{Warung Kaset}

Warung kaset (cassette stalls) distinguish themselves sonically from the other stalls in a traditional market by the loud recorded music they broadcast to passersby. The type of music played depends on the sales clerk, though sentimental pop ballads, often in English, are a frequent choice. These establishments make do with spartan decoration, relying on the sound of the music and the colorful cassette packages on display to attract customers. Many sell a range of other non-perishable items in addition to cassettes: plastic toys, batteries, headphones, and the like. Cassettes for sale in the stall are not displayed alphabetically, but are usually separated into unlabeled categories. In Jakartan cassette stalls the most common of these implicit classifications, judging from the identity of the artists represented in each section, are Western pop, pop Indonesia, dangdut, Javanese, Sundanese, Islamic, and children's music. The classification scheme does not usually distinguish between regional pop and traditional music recordings from the same region. In these warungs, Western music cassettes are usually placed on the highest shelves behind the counter, while Indonesian music is displayed on lower shelves and under the counter inside glass display cases. This practice appears to elevate foreign music to a higher status, though it may simply result from the desire to protect the stall's most expensive items from theft. Nevertheless, after visiting innumerable Indonesian cassette stalls, I concluded that the spatial separation between Indonesian and foreign music was carefully maintained in a manner suggesting that more than security concerns might be at stake.

In nearly all warung kaset, the customer has the option of trying out a recording on the stall's sound system before purchase, to test it for defects (which are rare, in my experience) and to determine if he or she likes the music. Usually the sales clerk opens the cassette's shrink-wrap with a small knife blade (if it hasn't already been opened) and then uses a small motorized device to fast-forward the tape a little to get past the leader (the blank space at the start of a tape). In Indonesia, leaders are rather lengthy - up to twenty seconds or so-a result of the local method of cassette duplication.

\footnotetext{
14 Franco Moretti notes a class-related effect in the differences between movie genre choices in video stores in New York City, where less overall genre variety (and thus more limited choices) is apparent in the offerings of stores located in lower-income areas compared to those in upper-income neighborhoods. In contrast, warung kaset generally contain a larger selection of certain types of indigenous genres (regional music, jaipongan, and dangdut, in particular) than do the import-dominated music boutiques in malls and therefore cannot be said to offer a more limited overall range of choices. See Franco Moretti, "Markets of the Mind," New Left Review 5 (2000): 111-15.
} 


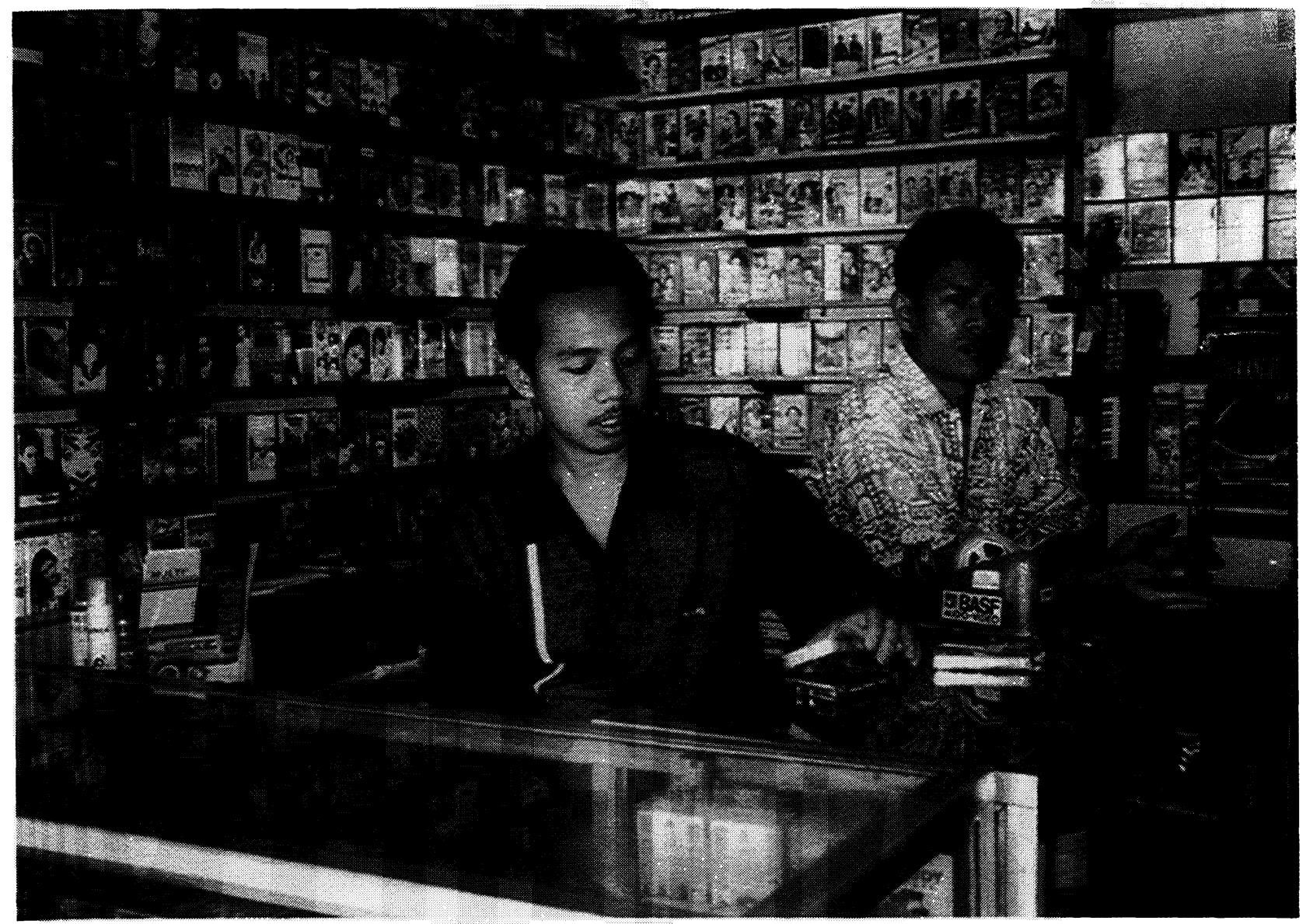

A cassette stall in Pasar Santa, Kebayoran Baru, South Jakarta. Photo by J. Wallach.

The clerk then places the cassette in the stall's tape deck and plays a segment of the first song at a volume sufficient to fill the entire space of the stall. The cassette continues to play until the customer asks to hear another song or tells the salesclerk he or she has heard enough. The salesclerk will then immediately play the same cassette that had been playing previously until another customer makes a request. In this way, the musical background of the stall is never silenced for long.

Jakarta warung kaset proprietors buy their cassettes in small amounts wholesale from distributors located mostly in the Glodok area of North Jakarta. They make choices regarding which cassettes to stock based upon previous sales, and in most cases do not buy more than one or two copies of a single title. As a result, customers wishing to purchase an especially popular cassette are often cheerfully told that it has sold out (habis). Stall proprietors will not stock titles they do not believe will sell to a broad public, thus cassettes of local traditional musics from islands other than Java and works by socially conscious, avant-garde recording artists such as Sawung Jabo, Djaduk Ferianto, and Sujiwo Tedjo are rarely found in warung kaset. 


\section{Mall Stores}

Jakarta's gigantic air-conditioned malls offer a cosmopolitan alternative to shopping in pasar tradisional (traditional markets). They are a place for the fashionable to see and be seen, and to experience a taste of global consumer culture. Like malls in the US, no Indonesian mall is complete without at least one store selling recorded music.

Targeted at middle-class and elite consumers, music stores in upscale malls are typically decorated with an eclectic, bewildering assortment of images from Western culture. A store window display in Jakarta's Plaza Senayan mall featured a portrait of Beethoven, a blown-up photograph of Kurt Cobain (the late singer of the American band Nirvana), a depiction of the Mona Lisa smoking a large marijuana cigarette, a poster of a Norwegian black metal band, and a Bob Marley album cover. One mall store, Tower Music, located in the fashionable Menteng shopping district, had a display of small flags on one of the shelves. The countries represented were Indonesia, the United States, Ireland, Japan, Germany, and Britain. There was no flag for Malaysia, Singapore, or any other neighboring Southeast Asian country, suggestive of a cosmopolitan music-scape based more on cultural power than geographical proximity. Even the name of the store evoked Tower Records, a transnational music retailer that had yet to reach Jakarta.

While all record stores in Indonesia sell some Indonesian recordings, music boutiques in upscale malls tend to carry mostly Western music. Moreover, in my explorations of music stores located in Jakarta's most exclusive malls-Plaza Indonesia, Pondok Indah Mall, Taman Anggrek, and Plaza Senayan-I found that compact disks actually outnumbered cassettes. Unlike warung kaset, mall stores generally sorted recordings alphabetically in labeled shelf categories. Imported music was divided according to genre (jazz, $R \& B$, country, etc.), while locally produced recordings were frequently relegated, irrespective of their particular genre, to shelves labeled "Indonesia" that took up as little as 10 percent of total shelf space. Dangdut albums, if present at all, accounted for less than 5 percent of shelf space; regional (daerah) genres were largely absent. While in upscale mall stores music always played in the background, there were no facilities for testing recordings one wished to buy. Clerks were not permitted to open the shrink-wrap of cassettes and compact disks for customers.

In short, mall music stores present themselves as portals to an imaginary realm of global consumer culture. Signs of local specificity that would place the store in an Indonesian context, including the Indonesian language, are minimized or eliminated in their decor. Indonesian music is marginalized as a marked category, while Western music and culture are represented in a spectacular fashion. Thus music boutiques in upscale malls are paragons of the same elite, xenocentric logic that is merely hinted at by the spatial arrangements in warung kaset. 
92 Jeremy Wallach

Large Music Stores

A third music retail alternative to cassette stalls and mall boutiques is made up of (the relatively few) large music stores located in major cities. These establishments, which offer far larger musical selections than either warung kaset or mall boutiques, are located in department stores such as Sarinah or the Pasaraya at Blok M, or are housed in stand-alone structures like Aquarius, a record store chain owned by one of Indonesia's largest national record companies. This section will investigate in detail the ways in which the Aquarius store in Jakarta displays its wares, which run the full gamut from Western classical music to traditional regional genres. In fact, the interiors of Aquarius and stores like it can be viewed as three-dimensional spatial representations of the entire Indonesian popular music field, which of course is not limited solely to musics that come from Indonesia.

The Aquarius music store located in the trendy Bulungan area of Blok M in South Jakarta consisted of two main rooms. The larger room held both Indonesian and Western compact disks (mostly the latter), Indonesian children's pop, and a large selection of Western cassettes, while a smaller one contained Indonesian cassettes. Interestingly, in the center of the "Indonesian" room there was an arrangement of tape players with headphones, with which customers could test cassettes. No such array was provided in the large room. ${ }^{15}$ These tape machines resembled those found in warung kaset, though the experience of trying a cassette was rendered somewhat more private by the headphones. I say "somewhat" because I often observed two or more customers trying to listen to a song through the same pair of headphones at the same time. The presence of this listening equipment appeared to be a concession to shoppers accustomed to the cassette-stall buying experience.

The Western music available in cassette format at Aquarius was divided into several specific subcategories, not all of which completely corresponded with conventional Western classifications. The shelf categories as they appeared in early 2000 are listed below in Table 2. The number in the far right column indicates the number of shelf units dedicated to each named category. Each shelf unit held about fifty different cassettes, depending on how they were arranged.

Displayed on a long, low, child-accessible shelf, Indonesian children's pop was the only indigenous musical category present in the large room. I suspect that the storeowners were concerned that middle- and upper-class consumers preoccupied with social prestige (gengsi) would not even want to enter the Indonesian music room. Such consumers often buy children's pop cassettes for their offspring; this practice is not a threat to gengsi because small children are not expected to have developed

\footnotetext{
15 In mid-2000, another playback device was installed near the entrance to the smaller room. This was a listening booth that played a limited assortment of new releases on compact disk, both Indonesian and Western, through an accompanying set of headphones. The listener was able to operate the controls in order to hear particular albums and tracks stored in the machine. Similar digital listening booths have become popular fixtures in large Western record stores, thus rather than constituting an extension of the Indonesian practice of trying out cassettes before purchasing, the presence of this particular playback device in the Aquarius store is better viewed as an example of transnational influences in record store commerce.
} 
cultivated musical tastes or to understand English lyrics. It may also be the case that pop anak-anak, a major musical genre in Indonesia, benefits from the fact that it lacks a real equivalent in the Western pop universe.

Table 2. Inventory of Cassette Categories at Aquarius Musik, Main Room

\begin{tabular}{|c|c|c|}
\hline Shelf Label & Contents & $\begin{array}{l}\text { Shelf } \\
\text { Units }\end{array}$ \\
\hline Classic & Western classical and light classical music. & 1 \\
\hline Instrumental & Western New Age and instrumental pop. & 1 \\
\hline Soundtrack & Recent Hollywood film soundtracks. & 1 \\
\hline Compilation & Collections of pop hits, mostly love songs. & 2 \\
\hline $\mathrm{Jazz}$ & Jazz-pop fusion, some traditional jazz. & 2 \\
\hline Alternative/Modern Rock & $\begin{array}{l}\text { Western rock bands sharing a rhetorically anti- } \\
\text { mainstream, punk-influenced aesthetic. }\end{array}$ & 2 \\
\hline Rhytm + Blues [sic] & American R\&B and hip hop. & 2 \\
\hline Dance & $\begin{array}{l}\text { Various Western electronic dance genres: house, } \\
\text { techno, etc. }\end{array}$ & 1 \\
\hline Rock + Pop & Western rock and pop artists. & 17 \\
\hline New Releases & Recent titles, both Indonesian and foreign. & 1.5 \\
\hline Top 40 & $\begin{array}{l}\text { Ranked best-selling albums, both Indonesian and } \\
\text { foreign. }\end{array}$ & 2 \\
\hline Children & Indonesian pop anak-anak (children's pop) & 1 \\
\hline
\end{tabular}

The remainder of the Indonesian music cassettes sold by Aquarius are located in a room to the far left of the store's front entrance. Its total inventory is a fraction of that in the large room (10 versus 33.5 shelf units), and the five categories that appear on shelf labels do not reflect the same level of genre specificity, as the table below illustrates. See Table 3, below.

In the large room near the entrance to the small one, two shelf units were devoted to displaying the store's forty top-selling cassettes of the week, both Indonesian and Western. This was one of the few sections of the store where imported and domestic music shared shelf space and seemed to compete with one another on equal footing. The following table is a list of the Top Forty best-selling albums for the week of January 22, 2000, as compiled by the Aquarius store. See Table 4, below. 
94 Jeremy Wallach

Table 3. Inventory of Cassette Categories at Aquarius Musik, Indonesian Room

\begin{tabular}{|c|c|c|}
\hline Shelf Label & Contents & $\begin{array}{l}\text { Shelf } \\
\text { Units }\end{array}$ \\
\hline Compilation & $\begin{array}{l}\text { Various artists, mostly collections of vintage } \\
\text { Indonesian pop songs. }\end{array}$ & 0.5 \\
\hline Indonesia & $\begin{array}{l}\text { Contemporary Indonesian pop, Indonesian } \\
\text { rock, alternative, } R \& B \text {, metal, and so forth. }\end{array}$ & 5 \\
\hline Dangdut & $\begin{array}{l}\text { Dangdut, dangdut trendy (hybrids of dangdut } \\
\text { and electronic dance music), orkes Melayu } \\
\text { (dangdut's historical precursor). }\end{array}$ & 1 \\
\hline Etnic [sic] & $\begin{array}{l}\text { Primarily pop daerah (regional pop) from } \\
\text { different parts of the archipelago, incl. Java, } \\
\text { Sunda, Maluku, Sumatra (Malay, Batak, and } \\
\text { Minangkabau), North Sulawesi (Manado), Irian } \\
\text { Jaya-even East Timor. Also a fair amount of } \\
\text { Javanese and Sundanese traditional musics. }\end{array}$ & 1 \\
\hline Unlabelẹd & $\begin{array}{l}\text { Indonesian jazz, jazz-pop fusion, and ethnic } \\
\text { fusion jazz; patriotic songs; keroncong; } \\
\text { Indonesian house music; "nostalgia" } \\
\text { collections. }\end{array}$ & 1 \\
\hline Rohani & $\begin{array}{l}\text { Western and Indonesian pop music with } \\
\text { Christian religious themes. } 16\end{array}$ & 1 \\
\hline Unlabeled subsection & Indonesian Islamic pop & 0.5 \\
\hline
\end{tabular}

16 Protestant Christian-themed popular music constitutes an alternate musical universe in Indonesia that encompasses styles as diverse as light pop, heavy metal, even dangdut. Pop Rohani recordings can be found in Jakarta's ordinary record shops as well as in a few specialized department stores targeting affluent members of Indonesia's Christian minority which sell all manner of Christian-themed products, including books, clothes, and wall hangings, in addition to cassettes and compact disks. A study of these establishments and the consumers who frequent them would be a valuable addition to our understanding of the growing role of Protestant Christianity in post-New Order Indonesia. 
Table 4. Top Forty Best-selling Albums at the Aquarius Musik Store, Week of January 22, 2000 Indonesian titles are marked with an asterisk $\left(^{*}\right)$

\begin{tabular}{|c|c|c|c|}
\hline No. & Artist & Album Title & Description \\
\hline 1 & The Corrs & MTV Unplugged & Western, quasi-Celtic pop \\
\hline 2 & Celine Dion & $\begin{array}{l}\text { All the Way: A Decade of } \\
\text { Song }\end{array}$ & $\begin{array}{l}\text { Western sentimental pop } \\
\text { ballads }\end{array}$ \\
\hline 3 & Westlife & Self-titled & Western "boy band" \\
\hline $4^{*}$ & Rossa & Tegar [Resolute] & $\begin{array}{l}\text { Pop kelas atas (upper-class } \\
\text { pop) }\end{array}$ \\
\hline $5^{*}$ & Chrissye & $\begin{array}{l}\text { Badai Pasti Berlalu [The } \\
\text { Storm Will Surely Pass] }\end{array}$ & $\begin{array}{l}\text { Newly arranged songs from } \\
\text { a classic } 1970 \text { s pop album }\end{array}$ \\
\hline $6^{*}$ & Various & $\begin{array}{l}\text { Hard Rock FM Indonesia } \\
\text { Klasik }\end{array}$ & $\begin{array}{l}\text { Compilation of Indonesian } \\
\text { rock bands }\end{array}$ \\
\hline $7^{*}$ & Padi & $\begin{array}{l}\text { Lain Dunia [Another } \\
\text { World] }\end{array}$ & Pop alternatif \\
\hline $8^{*}$ & Dewa 19 & Best of Dewa 19 & Pop alternatif \\
\hline 9 & Boyzone & By Request & Western "boy band" \\
\hline $10^{*}$ & Melly & Self-titled & Pop alternatif \\
\hline 11 & Bryan Adams & The Best of Me & Western mainstream rock \\
\hline 12 & Various & Everlasting Love Songs 2 & $\begin{array}{l}\text { Western sentimental pop } \\
\text { ballads }\end{array}$ \\
\hline $13^{*}$ & Sheila on 7 & Self-titled & Pop alternatif \\
\hline 14 & Metallica & SEM 2 & Western hard rock/metal \\
\hline $15^{*}$ & Bunglon & Biru [Blue] & $\begin{array}{l}\text { Smooth jazz-influenced } \\
\text { pop }\end{array}$ \\
\hline 16 & Sheila Majid & Kumohon [I Beseech] & $\begin{array}{l}\text { Malaysian jazz-influenced } \\
\text { pop }\end{array}$ \\
\hline 17 & Alanis Morissette & Unplugged & Western alternative rock \\
\hline 18 & $\begin{array}{l}\text { Richard } \\
\text { Clayderman }\end{array}$ & Chinese Garden & $\begin{array}{l}\text { Western pop classical } \\
\text { crossover }\end{array}$ \\
\hline 19 & Korn & Issues & $\begin{array}{l}\text { Western "hip metal" (hip } \\
\text { hop + metal) }\end{array}$ \\
\hline 20 & Various & '99: The Hits & $\begin{array}{l}\text { Western Top } 40 \\
\text { compilation }\end{array}$ \\
\hline 21 & $\begin{array}{l}\text { Rage Against the } \\
\text { Machine }\end{array}$ & The Battle of Los Angeles & $\begin{array}{l}\text { Western "new school" } \\
\text { hardcore/hip metal }\end{array}$ \\
\hline $22^{*}$ & Sherina & $\begin{array}{l}\text { Andai Aku Besar Nanti } \\
\text { [When I Grow Up] }\end{array}$ & $\begin{array}{l}\text { Children's pop (pop anak- } \\
\text { anak) }\end{array}$ \\
\hline 23 & Various & Forever & $\begin{array}{l}\text { Western sentimental pop } \\
\text { ballads }\end{array}$ \\
\hline $24^{*}$ & $\begin{array}{l}\text { Dian Pramana } \\
\text { Poetra }\end{array}$ & Terbaik [Best] & "Upper-class" pop \\
\hline
\end{tabular}


96 Jeremy Wallach

\begin{tabular}{|l|l|l|l|}
\hline $25^{*}$ & Syaharani & $\begin{array}{l}\text { Tersiksa Lagi [Suffering } \\
\text { Again] }\end{array}$ & Vocal jazz \\
\hline 26 & Savage Garden & Affirmation & Western mainstream pop \\
\hline 27 & George Michael & Songs from the Last Century & Western mainstream pop \\
\hline 28 & Metallica & S E M 1 & Western hard rock/metal \\
\hline 29 & Santana & Supernatural & $\begin{array}{l}\text { Western Latin-crossover } \\
\text { pop rock }\end{array}$ \\
\hline $30^{*}$ & Rita-Sita-Dewi & Satu [One] & Upper class pop \\
\hline $31^{*}$ & Romeo & Self-Titled & Upper class pop \\
\hline $32^{*}$ & Ruth Sahanaya & Kasih [Love] & Upper class pop \\
\hline 33 & Various & Lis for Love & $\begin{array}{l}\text { Western sentimental love } \\
\text { ballads }\end{array}$ \\
\hline 34 & Foo Fighters & There Is Nothing Left to Lose & Western alternative rock \\
\hline 35 & Eric Clapton & Chronicles & Western mainstream rock \\
\hline $36^{*}$ & Purpose & Tiger Clan & Ska \\
\hline 37 & Various & The End Of Days & $\begin{array}{l}\text { Hollywood movie } \\
\text { soundtrack }\end{array}$ \\
\hline 38 & Guns 'n' Roses & Live Era '87-93 & Western hard rock \\
\hline 39 & Various & American Pie & $\begin{array}{l}\text { Hollywood movie } \\
\text { soundtrack }\end{array}$ \\
\hline $40^{*}$ & Noin Bullet & Bebas [Free] & Ska \\
\hline
\end{tabular}

This list is fairly representative: the ratio of Indonesian to foreign entries is 2:3 (16 to 24; on other weeks the balance was tipped more favorably toward the former), and it is dominated by musical genres commonly associated with middle-class consumers: Western pop, sophisticated "upper-class" Indonesian pop, and Western hard rock music. ${ }^{17}$ I never saw a dangdut cassette included in the Aquarius Top Forty. While in the above table Western recording artists occupy the top three slots, on other weeks Indonesian recordings held those positions. Overall, the Top Forty lists demonstrated an incompatibility between the levels of attention enjoyed by imported and Indonesian music within the frame of the Aquarius store. While imported music attracted many buyers, Indonesian music also sold well despite its spatial marginalization and the middle-class, gengsi-conscious character of the store's regular clientele.

\section{Mobile Cassette Vendors}

A final type of commercial music retailer is worth mentioning here. Along with a veritable army of other mobile salesmen who traveled through my neighborhood in South Jakarta selling everything from brooms to hot sate ayam (chicken satay), a mobile cassette vendor would make his way through the streets pushing a wooden cart into

17 The list also indicates the preference among many Indonesian consumers for greatest-hits compilations (eleven in total, seventeen if one counts albums containing "live" recordings or new studio arrangements of familiar songs) over albums of new, unfamiliar material. 
which a car stereo system was installed. The cassettes he sold, all legitimate copies, not pirated, were intended to appeal to the servants and warung proprietors of the neighborhood, not its more affluent residents. Not surprisingly, the selection of recordings was dominated by dangdut and regional music from Sunda, Central Java, and East Java, including cassettes of village folk genres such as Sundanese kliningan that were difficult to find in Jakarta cassette stores.

In addition to cassettes, the "circling around dangdut" (dangdut keliling-keliling) vendor sold toys, brushes, and other household items. His approach was signaled by the dangdut music blaring out of the cart's speakers as he walked down the street. The tape deck installed in the cart was also used to try out cassettes for potential customers. While Western music was not wholly absent from his wares, the circlingaround-dangdut seller seemed to circumvent Jakarta's prestige hierarchy of genres by unabashedly targeting rural migrants, not city people, as his primary customers.

\section{Cassette Piracy and Vendors of Illegally Copied Cassettes}

No inventory of the sites of music commerce in Indonesia would be complete without some remarks on cassette piracy. With most legitimate Indonesian cassettes costing over Rp. 12,000 each, it is hardly surprising that vendors of illegally copied versions priced at Rp. 6,000 or less can attract many buyers. The quality of these pirated versions varies, but they are often not markedly inferior to the originals. Color copiers have enabled pirates to reproduce accurately the original graphics of legitimate releases, and high-quality cassette duplication machines can approximate the original's sound quality. In addition to selling illegal copies of complete albums, pirated cassette vendors sell unauthorized compilations of current hit songs. These are usually either dangdut or pop compilations, and their graphics, usually a collage of miniaturized cassette covers representing the different songs, vary widely in sophistication. One advantage the pirated compilations have over legitimate hits collections is that they can combine songs released by different recording companies, since they are not bound by copyright restrictions. Thus, pirated hits compilations are not only cheaper, but also more likely to contain all the current hit songs.

Surprisingly, not all Indonesian musicians whom I interviewed vehemently opposed piracy. After all, if one's work was pirated, it indicated persuasively that one's music had achieved a measure of mass acceptance and that consumer demand existed for it. During an interview, Harry Roesli, one of Indonesia's foremost composers/ musicians/social critics, proudly showed me a pirated hit song compilation that contained his controversial composition "Si Cantik" ("Ms. Beautiful," a satirical song about a granddaughter of then-President Suharto who was suspected of selling the drug Ecstasy) as the first track. He considered the cassette proof that the subversive political messages contained in his music were successfully reaching the masses of ordinary people. Many underground scene members claimed that the mainstream acceptance of Indonesian underground music was proven by the fact that some extreme metal bands' cassettes (usually those released by major labels) had been pirated and were being sold in outdoor markets alongside the customary rock, pop, and dangdut offerings. 
98 Jeremy Wallach

Buyers of pirated cassettes were categorically assumed to be members of the working class by my consultants. Members of the middle class were purportedly too concerned with status (gengsi) to consider purchasing such items, which were thought to be of inferior quality. The poor, on the other hand, were said to have the attitude of asal denger aja (as long as you can hear) and to have no qualms about the uneven quality of illegally copied cassettes. Pirated cassettes thus occupy the lowest prestige level among recorded musical artifacts. They are sources of popular pleasure, but, unlike legitimate commercial cassettes, do not act as indices of cultural capital even if they happen to be illegal copies of Western music.

\section{Sources for Underground Music and Accessories}

In an interview posted on an Indonesian fanzine Web site, Robin Malau, a veteran musician in the Bandung underground scene, comments:

[K]ebanyakan cara indie jualan, sampe-sampe ngga berasa bahwa mereka itu sedang melakukan transaksi dagang ... antar teman, promosi mulut ke mulut ... seperti untuk kalangan sendiri gitu ... bagus lho . . . positifnya, itu juga salah satu cara approach yang lebih akrab kepada pasar, lagian mo begimana lagi?

For the most part the indie way of selling is such that it is not felt that they are making a commercial transaction ... between friends, word-of-mouth promotion ... like for their own social circle, y'know? ... it's nice ... the positive thing is that it's also one kind of approach to the market that is friendlier-why would you want anything more? ${ }^{18}$

In keeping with the point of view quoted above, underground cassettes are, as a rule, not found in mall stores, cassette stalls, or any other conventional retail outlet. It is, in fact, illegal to sell them, as the Indonesian government does not collect any tax on the transaction. ${ }^{19}$ Legitimate (non-pirated) commercially released cassettes in Indonesia usually come with a small strip of paper indicating that the manufacturer has prepaid a percentage of their value to the government. In order to purchase underground music cassettes that lack these required strips of paper, one must know someone in the underground scene, attend a concert event, or travel to one of a small number of urban specialty shops which sell underground music and accessories.

Most underground concert events include itinerant vendors who set up shop on a blanket either inside or on the grounds outside the concert venue. Their wares vary, and can include t-shirts, stickers, cassettes, compact disks, fanzines, and sewn-on patches. Significantly, this is one place where imported and indigenously produced

\footnotetext{
18 Interview with Robin Malau posted on Puppen's official Web site, www.not-a-pup.com/multi.htm, ellipses in the original.

19 A notable exception is Robin's band Puppen, the members of which decided to pay the value-added tax required by law in order to sell their album in mainstream retail outlets like Aquarius. Puppen was one of the few underground bands to take this bold and costly step, which proved to be a wise investment: during one week in May 2000, Puppen's latest cassette release was ranked at number 38 in the Aquarius store's Top Forty, outselling the most recent album by Sting.
} 
recordings are generally sold side-by-side; the peddler's wares are not usually separated by their country of origin but rather mixed together, arranged alphabetically or in no particular order at all. Only an insider to the music scene would be able to distinguish foreign groups' cassettes from Indonesians', since most local band names are in English and their album graphics make use of similar genre-based iconography. Of course, the sharp difference in cassette price persists, although stickers and other accessories sporting Western band logos are usually pirated and thus do not cost more than those with Indonesian band logos, which are sometimes also unauthorized copies.

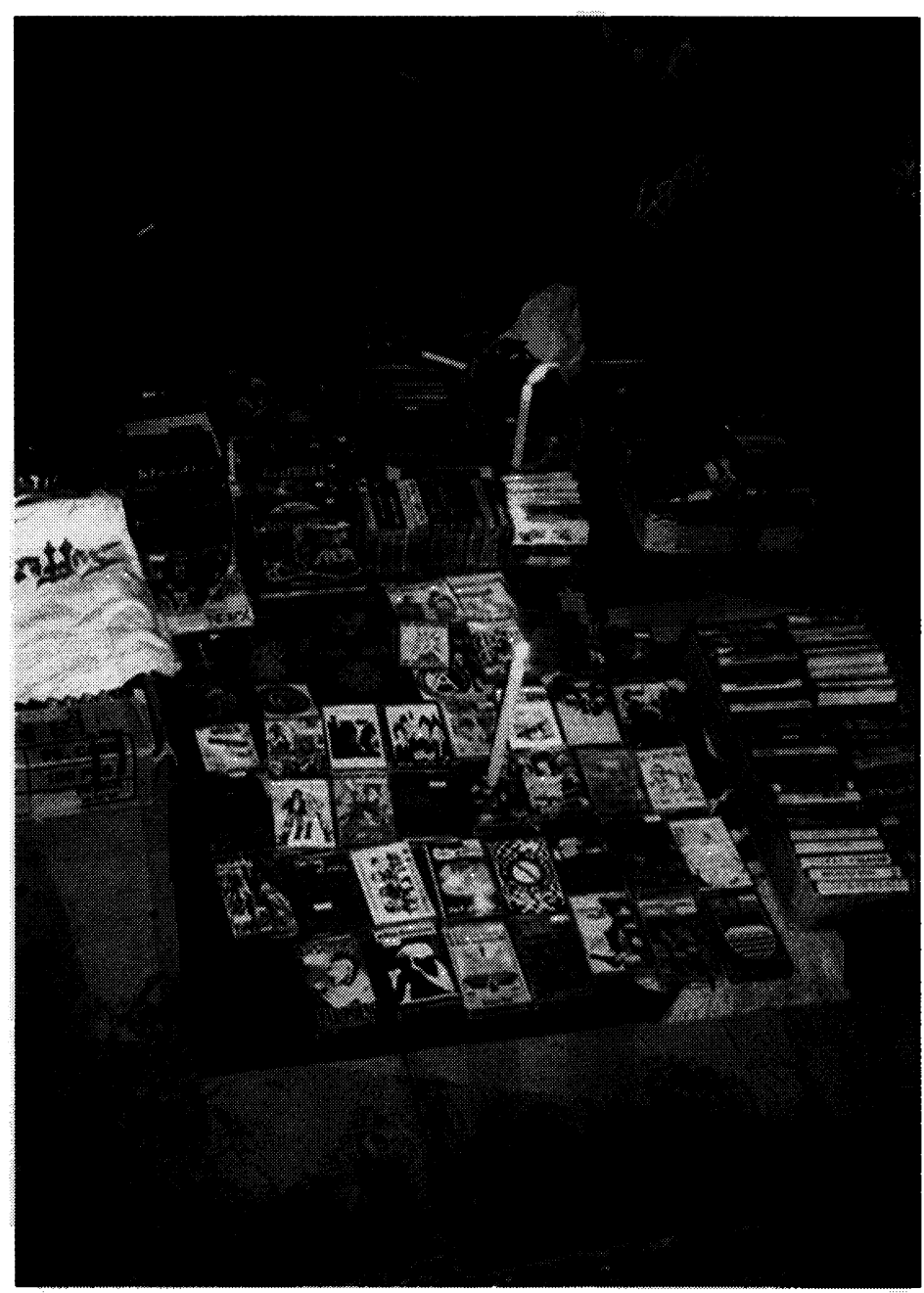

Cassettes and compact disks for sale at an underground concert event in Pancoran, South Jakarta. Photo by J. Wallach.

\section{Reverse Outfits}

The oldest standing retail establishment for the sale of underground music and accessories is located not in Jakarta but in a quiet residential neighborhood in the West Javanese capital city of Bandung. Since June 1993, Reverse Outfits has sold both imported and Indonesian underground music. The store is located on the property of Richard Mutter, an Indo (part native, part European) in his early thirties. Richard is the 
100 Jeremy Wallach

former drummer of Pas (Precise), an alternative rock group that originated in the underground scene and released a cassette on a small independent label in 1994, but has since released four albums for the large national recording company Aquarius Musikindo and met with modest commercial success. The Reverse Outlets store is part of a complex that includes a rehearsal/recording studio for Richard's record label, 40.1.24 (named after the neighborhood's postal code), and computer facilities for creating posters and graphics. Originally a source primarily for imported underground music, which the store purchased via mail order, the inventory of Reverse Outfits shifted dramatically between 1997 and 2000 as a result of two factors.

First, the economic crisis and the steep devaluation of the rupiah made imported cassettes and compact disks prohibitively expensive, as the store not only had to pay full price for each item in a foreign currency (most often US dollars), but also cover substantial overseas shipping and handling costs. Thus the amount of imported music on sale at Reverse Outfits declined considerably after 1998. However, this lost inventory was replaced by way of a second development: the exponential increase of independently produced Indonesian underground music recordings over the same period.

Like Aquarius, Reverse Outfits is divided into two rooms. During my first visit to the store in the fall of 1997, the inner room was used to display recordings from overseas, while the outer room contained a glass display counter, similar to those found in warung kaset, filled with domestically produced underground music. While imported underground music was usually sold in the form of compact disks, Indonesian underground music, like most music recorded in Indonesia, was only available on cassette. As of September 2000, only one underground label had ever released a compact disk: a band compilation 40.1.24 Records produced in 1997 that could still be purchased at Reverse Outfits three years later. The economic crisis prevented any subsequent compact disk releases, but the number of new cassettes continued to grow. By the time of my return to Indonesia in 1999, Reverse Outfits had consolidated its musical inventory. Its few remaining imported compact disks were placed on the top two shelves in the front room's glass display case, while Indonesian underground cassettes were displayed in no particular order on the bottom shelf. Thus, even in this context the hierarchical spatial separation between foreign and indigenous music was maintained.

In addition to Reverse Outfits, a small but growing number of underground boutiques (toko underground) had opened in Jakarta, Bandung, Surabaya, Denpasar, and other cities by 2000 . These establishments are often owned and operated by veteran underground scene members (often those who have graduated or dropped out of university and are in need of earning their livelihoods) and sometimes include rehearsal and recording studios as well. Studio Inferno in Surabaya even has its own Internet café. These outlets, like Reverse Outfits, sell both foreign and Indonesian shirts, stickers, hats, fanzines, and recordings and are important hangout spots (tempat nongkrong) for members of the scene. Many stores, such as the creatively named Ish-Kabible Sick Freak Outfits Shop in Jakarta, produce their own T-shirts and 
stickers. ${ }^{20}$ Underground boutiques exist in a gray area between the Indonesian formal and informal economic sectors, and while they depend on impersonal, commercial transactions to some extent for survival, they adhere to the underground's ethic of grassroots authenticity and anti-commercial artistic purism. For example, while Reverse Outfits stocks Pas's major label cassette releases, all other titles they sell are releases from small independent labels. The other boutiques I visited did not sell any "major label" Indonesian cassettes at all, even those released by groups formerly part of the underground scene.

\section{Conclusions: Recorded Music, Display, and Musical Value}

Cassettes stores in Indonesia display hegemonic and xenocentric understandings of musical genres that ghettoize and subordinate indigenously produced music to international music products and maintain a segregated, unequal relationship between them. The two partial exceptions to this rule mentioned in this essay, Christian (Rohani) music and underground music, are notable for their connection to selfconscious minority subcultures organized around the interpretation of cultural texts and forms produced outside of Indonesia. The presentational logic that relegates musically similar Indonesian and Western recordings to separate areas of the store preserves the myth that these musics are incomparable despite their sonic similarity. In the larger stores dominated by Western imports, this logic deceptively suggests that Indonesian-produced popular music is enjoyed by a minority of Indonesia's consumers, despite sales figures that consistently demonstrate otherwise. While perhaps preserving a sense of Indonesian cultural uniqueness, this separation can also present Indonesian popular music as second-class and less worthy of serious attention.

In addition to the lack of differentiation between Indonesian pop genres in most Indonesian music stores, "regional" or "ethnic" music is also a catchall category under which the most traditional and the most contemporary styles are displayed side by side. The regional category is thus even less differentiated than the Indonesian national music category, which is always at the very least divided between pop and dangdut. Dangdut, the most popular style in Indonesia, is usually marginalized in store displays. Conversely, Western music, a minority taste, is highlighted and carefully categorized by subgenre. An alternate display strategy of placing Western and Indonesian rock, for example, in one shelf category sorted alphabetically by artist with no regard to country of origin still seems unthinkable in mainstream outlets and even in many underground music stores-though the boundaries between foreign and indigenously produced music have clearly eroded somewhat in the underground scene. I would suggest that one reason for this is that Western and Indonesian musics are perceived as existing on different ontological as well as economic planes.

${ }^{20}$ According to Robin Hutagaol, the store's proprietor, the name is a pun on "ishkabibble," an obscure Yiddish-American colloquialism he encountered once in a dictionary of American slang. In addition to running Ish-Kabible, Robin plays drums and sings with the underground band Brain the Machine, which describes its music as "industrial hardcore progressive." 
102 Jeremy Wallach

Reasons underlying the incommensurable categorical differences between Indonesian and Western music are summed up by the term gengsi, status consciousness. Indonesian popular music, no matter how Westernized, is considered of lesser status than "international" Anglo-American music. Indonesian music requires less cultivation (apresiasi) to enjoy and is therefore more accessible to non-elites. According to the widespread xenocentric view of musical value in Indonesia, the musics of the village are kampungan, repellently backward and low-class, while even higher status Indonesian pop still cannot aspire to the greatness of international pop, and moreover is forever subject to the accusation of simply imitating Western originals.

Despite the apparent investment made by music retailers in keeping Indonesian and foreign music separate and unequal, it is important to emphasize that the categorical and presentational logics of Indonesian record stores discussed in this essay contrast sharply with those of most Indonesian consumers. In general, Indonesians do not strictly segregate their recorded music collections into Western and Indonesian categories, and they use more differentiated genre labels to describe Indonesian popular music than appear on record store shelves. For example, Indonesian teenagers regularly use labels such as rock, underground, rap, ska, metal, and erenbi $(\mathrm{R} \& \mathrm{~B})$ when discussing the particular musical styles of Indonesian recording artists. Nevertheless, I found that the discursive divide between Indonesian and foreign was very much present in statements young people made about the value of different popular musics, as was the suspicion that Indonesian versions of Western genres were derivative and inferior. Thus the Indonesian music fan is suspended between doubts about the authenticity of Westernized pop music and misgivings about the village backwardness of musics regarded as authentically Indonesian. This state of ambivalent suspension leads to many creative attempts at solutions, and the younger generation's quest for an authentically Indonesian modern music continues.

Trivial and ephemeral though its products may be, popular music provides the heartbeat for all modern societies and can reveal much about the cultural dynamics and deep contradictions of contemporary national cultures. In Indonesia a central tension exists between the longing for a solidary, egalitarian national community on one hand and for modernity, affluence, identity, and consumerist lifestyle-for social distinction-on the other. The energy exerted in the denunciation of dangdut music is a salient example of how some Indonesians aspire to modernity by denigrating a cultural form that is perceived as antithetical to this aspiration. Indonesia is often rightfully celebrated for its "unity in diversity" style of nationalism and for the chaotic but relatively peaceful co-existence of cultural alternatives that seems to define everyday social existence in the country, particularly in urban areas after the collapse of the New Order. This diversity is certainly exemplified by the sheer variety of popular music genres for sale in Indonesian cities, but what is too often overlooked is that this exuberant and dizzying array of simultaneous cultural alternatives is not immune from the hierarchical imperatives of modernization nor the neocolonial attitudes of national elites. Indeed, the regime of cultural value that drives contemporary Indonesians' quest for social distinction in the realm of music consumption is often based, sadly, on precisely those xenocentric attitudes that Third World nationalisms had once attempted to eradicate. 